\title{
Length-weight relationships and condition factors of the sand smelt Atherina boyeri (Risso, 1810) estimated from commercial and experimental catches in Lake Trichonis (Western Greece)
}

\author{
Alexandra DOULIGERI ${ }^{1}$, Ioanna TSIONKI ${ }^{2,3}$, Olga PETRIKI ${ }^{3}$, \\ Dimitrios K. MOUTOPOULOS ${ }^{1, *}$ and Maria Th. STOUMBOUDI ${ }^{3}$ \\ ${ }^{1}$ Department of Animal Production, Fisheries and Aquaculture, \\ University of Patras, Mesolongi, Greece \\ ${ }^{2}$ Laboratory of Zoology Biological Applications and Technology Department, Laboratory of \\ Zoology, University of Ioannina, 45110 Greece \\ ${ }^{3}$ Institute of Marine Biological Resources and Inland Waters, Hellenic Centre for Marine \\ Research, Anavyssos, Attica, Greece \\ *Corresponding author, e-mail: dmoutopo@upatras.gr
}

Total length-weight relationships (LWRs) from 3583 individuals of Atherina boyeri (Risso, 1810) caught in Lake Trichonis (Western Greece), using a commercial encircled net and experimental Nordic type benthic and pelagic multi-mesh gillnets, were estimated during 2019-2020. The variation of the parameter $b$ for all seasons combined was significantly allometric, for both encircled towed and gillnets, with a quite robust fit ( $R 2$ equals 0.925 and 0.947 , respectively) and values equal to 2.254 and 2.089, respectively. The specimens were significantly lighter in summer than in the other seasons. The slopes of the LWRs significantly differ between seasons and exhibited relatively low values when compared to other ecosystems worldwide and in the same ecosystem in previous periods of time. The estimated values of the Le Cren index were significantly higher than the Allometric and the Fulton ones.

Key words: body size; encircled towed gears; gillnets, Greece

\section{INTRODUCTION}

Atherina boyeri (Risso, 1810) (class Atheriniformes, family Atherinidae) is an euryhaline teleost fish species inhabiting marine, brackish and inland waters (KOTTELAT \& FREYHOF, 2007). The species is found in the eastern Atlantic, from Portugal to Mauritania, and throughout the Mediterranean and the Black Sea. It also forms isolated marine populations at the coasts of England and the Netherlands (QUIGNARD \& PRAS, 1986). The most important populations of $A$. boyeri in Greek lakes are found in Lake Trichonis (Western Greece) and to a lesser extend in Lakes 
Vistonis (Northern Greece) and Kourna (Crete). In Lake Trichonis, where it has been introduced naturally via the Acheloos River, becoming abundant and with a mean production of 500 tons per year it is the most important source of income for the local fishermen (DAOULAS et al., 1993; LEONARDOS 2001).

In this study, annual and seasonal estimates of length-weight relationships (LWRs) for $A$. boyeri were estimated from fish captured by both commercial (i.e., encircled net) and experimental fishing gears, during 2019-2020. We also present estimations of three different condition factors that can be used as indices of the fish condition and the trophodynamics of the ecosystem under study (MOUTOPOULOS et al., 2011), which might further reduce the uncertainty raised by the estimation of fish growth. LWRs for the species in Trichonis are available from previous studies (LEONARDOS, 2001; STOUMBOUDI et al., 1997; PANAGIOTOU, 2014). However, these studies are based on annual estimates (thus lacking seasonal information, related to spawning activity), deriving from samples caught during 1988-1993 by commercial small-scale and beach seine nets, which may bias the representation of the whole population in the samples. In this framework, our results could be useful in a long-term monitoring program of this commercially important species regarding the evaluation of its population stock.

\section{MATERIAL AND METHODS}

Monthly samples of $A$. boyeri were obtained on board from Lake Trichonis (Latitude: $38^{\circ} 33^{\prime} 0.59^{\prime \prime} \mathrm{N}$, Longitude: $\left.21^{\circ} 33^{\prime} 8.99^{\prime} \mathrm{E}\right)$ during 2019-2020 (10 monthly samples during May 2019 to February 2020), using a commercial encircled nets (with a maximum length of up to $150 \mathrm{~m}$, a height up to $30 \mathrm{~m}$ and a minimum mesh size of $6 \mathrm{~mm}$ ) complemented with the use of light (up to 3 electric lamps with maximum light intensity of $1500 \mathrm{~lm}$ ), at depths greater than $35 \mathrm{~m}$ which are exclusively used in this Lake for catching $A$. boyeri (more details for that gear can be found in PETRIKI et al. 2021). Experimental, Nordic type benthic (30 m of length, $1.5 \mathrm{~m}$ of height each, with mesh size range between 5 and $55 \mathrm{~mm}$ ) and pelagic (6 m of length, $27.5 \mathrm{~m}$ of height each, with mesh size range between 6.25 and $55 \mathrm{~mm}$ ) (Comité Européen de Normalisation, CEN 2005) nets were seasonal (4 samples in March, May, August and November 2019) on board sampled. More details on the sampling scheme are presented in PETRIKI et al. (2021). All individuals were measured for total length to the nearest $1 \mathrm{~mm}$ and weight to the nearest $0.01 \mathrm{~g}$.

LWRs were estimated through the relationship $\mathrm{W}=\mathrm{a} \cdot \mathrm{TL}^{\mathrm{b}}$ (LE CREN, 1951), where $\mathrm{W}$ is the wet weight, TL the total length and a and b the intercept and the slope of the relationship respectively. To verify if $b$ value was significantly different from the isometric growth $(\mathrm{b}=3, \mathrm{P}$ $<0.05)$ Student's t-test was used. LWRs were separately estimated by season and Analysis of Covariance (ANCOVA; ZAR, 1999) was used to test for differences on the LWR parameters between pairs of seasons. Three different indices of condition factors were also estimated; (a) Le Cren $\mathrm{K} 1=\mathrm{W} / \mathrm{We}$, where We is the predicted weight derived from the LWR (Le Cren, 1951), (b) Allometric $\mathrm{K} 2=\mathrm{W} / \mathrm{TL}^{\mathrm{b}} \cdot 10^{3}$ (BOLGER \& CONNOLLY, 1989) and (c) Fulton $\mathrm{K} 3=\mathrm{W} / \mathrm{TL}^{3} \cdot 10^{5}$ (BAGENAL \& TESCH, 1978). One and Two-way Analysis of Variance (One- and Two-way ANOVA) were also used to test for differences among seasonal and gear combinations for the estimated indices.

\section{RESULTS AND DISCUSSION}

The TL of all $A$. boyeri specimens examined $(\mathrm{N}=3583)$ ranged from 48 to $116 \mathrm{~mm}$ with a mean length of $77.2 \mathrm{~mm}$ (SD: 12.9) (Table 1) and the estimated LWR was highly significant $(\mathrm{P}<0.05)$ with $\mathrm{r}^{2}$ value equal to 0.929 . The TL of all the specimens caught by the encircled net ranged from 50 to $115 \mathrm{~mm}$ (mean length 79.58 $\mathrm{mm}, \mathrm{SD}: 11.01)$ and the estimated LWR had a robust fit $\left(r^{2}=0.925, P<0.05\right)$. The specimens caught by gillnets had a wider TL range from 48 to $116 \mathrm{~mm}$ (mean length $74.21 \mathrm{~mm}$, SD: 14.5) and the estimated LWR had also a good fit $\left(\mathrm{r}^{2}=\right.$ 0.947, $\mathrm{P}<0.05$ ).

The value of the exponent $\mathrm{b}$ estimated for all specimens (combined season and gears) 


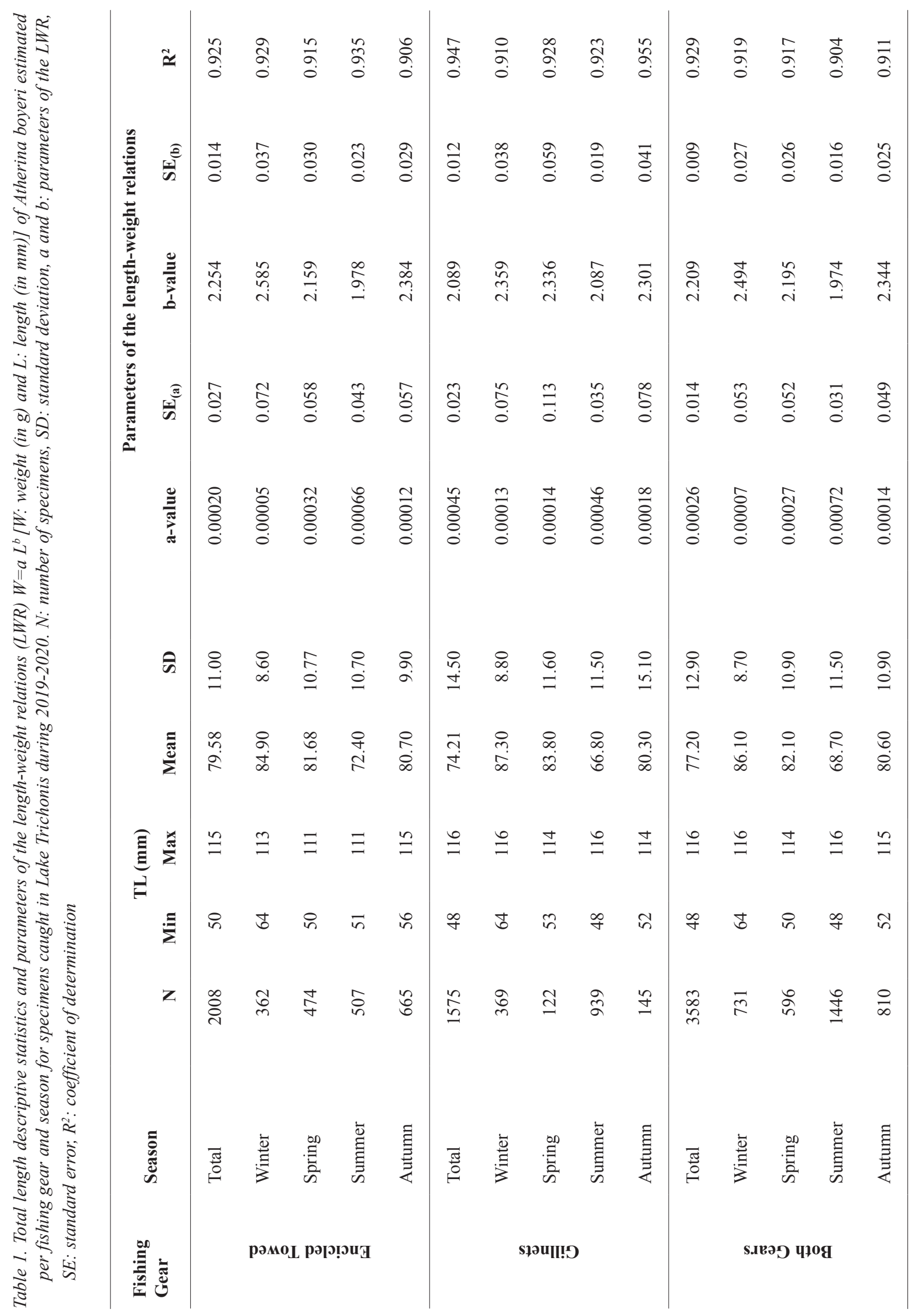



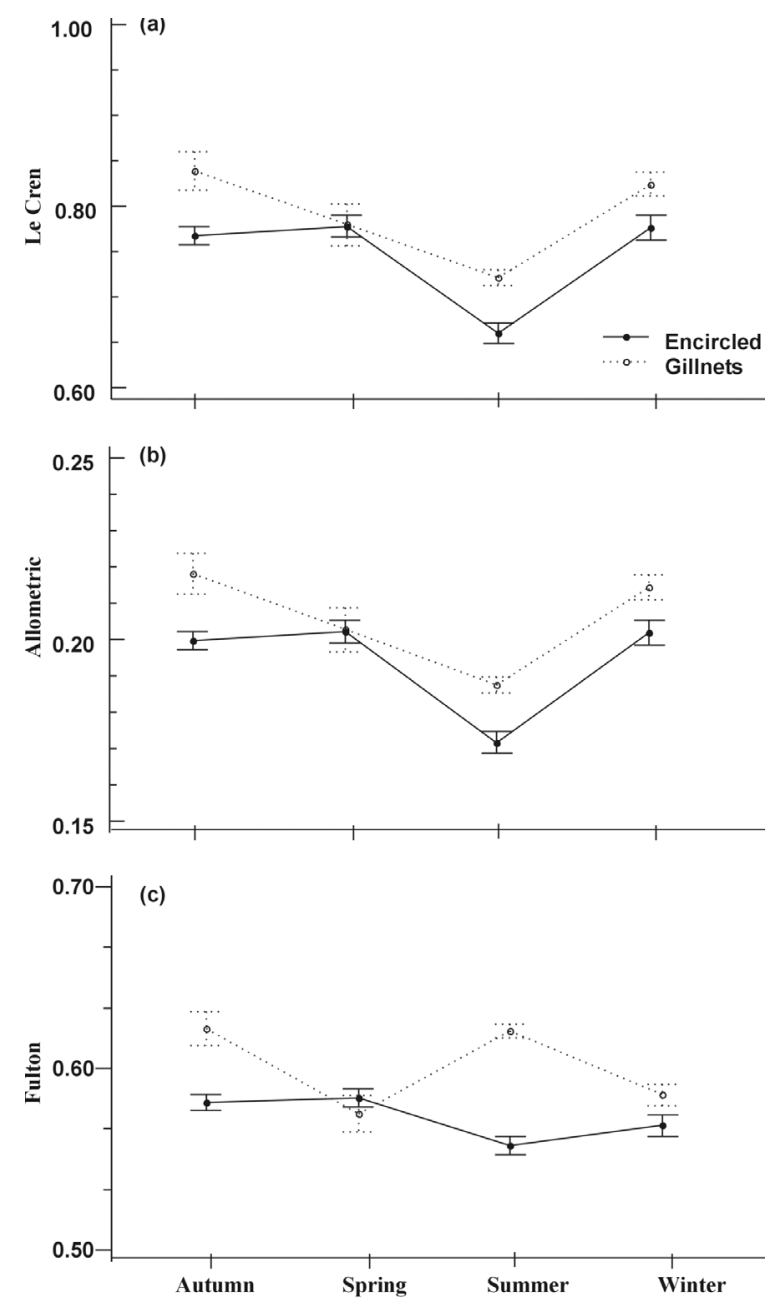

Fig. 1. Seasonal variation of (a) Le Cren, (b) Allometric and (c) Fulton condition factors of Atherina boyeri caught by encircled towed fishing gear and Nordic type benthic and pelagic multi-mesh gillnets in Lake Trichonis during 2019-2020

was significantly lower than 3 (Student's t-test; $\mathrm{P}<0.05$ ) (Table 1). The highest value of $\mathrm{b}$ was 2.585 estimated for the specimens caught by the encircled net in winter, whereas the lowest value was 1.974 estimated for the specimens caught by both gears in summer. In general, the highest $b$ values were estimated for winter samples and the lowest for the summer ones (Table 1). ANCOVA analysis also proved that the estimated LWRs exhibited significant $(\mathrm{P}<0.05)$ differences with season (Table 2).

All the estimated condition factors were significantly (One-Way ANOVA; $\mathrm{F}=21.35 ; \mathrm{P}<0.05$ ) the lowest during summer (Fig. 1), independent of the gear used (Two-Way ANOVA; F>21.35; $\mathrm{P}<0.05$ ), with the Le Cren index being significantly (One-Way ANOVA; $\mathrm{F}=49.19 ; \mathrm{P}<0.05$ ) higher than the other indices (Fig. 1a). The only exception from the above pattern was the Fulton index for gillnets exhibiting high value in summer that was significantly (Two-Way ANOVA; $\mathrm{F}=42.50 ; \mathrm{P}<0.05)$ higher than the one estimated for the encircled net (Fig. 1c). The Allometric index exhibited the lowest values, as it incorporates the value of the exponent $b$ of the LWR, whereas, Le Cren and Fulton indices do not (KYRITSI \& KOKKINAKIS, 2019).

Seasonal fluctuations in parameter $\mathrm{b}$ and condition factor values may be attributed either to reproductive and nutritional/ecological issues (i.e. feeding rate, maturity stage and spawning) or even to abiotic parameters i.e. the water's abiotic parameters (WOOTTON, 1999). In the present study, the seasonal $\mathrm{b}$ values and the condition factor indices were in general lowest during summer. This may be attributed to the energy that the species allocates for reproduction, since its reproductive period extends from March to September in Trichonis (KASPIRIS, 1998), as well as in other Balkan ecosystems, e.g. the Mala Neretva River, in Croatia (BARTULOVIĆ et al., 2004, 2006), in addition to the lowest food availability occurring in the summer and early autumn and the highest food resources i.e., large Copepods, were recorded during winter and spring (DOULKA et al., 2013).

The $b$ values estimated in the present study (ranged between 1.974 and 2.585 depending on the gear and the season) were lower than those reported in the Fishbase (FROESE \& PAULY, 2019). Thus, in our study, specimens were assumed to be lighter of a given length, when compared with other ecosystems worldwide, as well as to the same ecosystem in the past years (Table 3). Taking into consideration the LWR studies conducted for the species in Trichonis across the last 30 years (Table 3 ), a significant decrease of the mean annual $b$ value was exhibited; from 3.210 in 1988-1990 (STOUMBOUDI et al., 1997) and 3.180 in 1992-1993 (LEONARDOS, 2001), to 3.040 in 1997 (KASPIRIS, 1998) and 2.209 during 2019-2020 (present study). This pattern is dif- 
Table 2. Results of the analysis of covariance (ANCOVA, $P<0.05)$ for pairs of length -weight relations (LWRs) on Atherina boyeri specimens caught in Lake Trichonis during 2019-2020 for different gear and season combinations. a and b: parameters of the LWR; ns: non-significant difference $(P>0.05)$, *: significant difference $(P<0.05)$

\begin{tabular}{|c|c|c|c|c|c|c|c|}
\hline \multirow{2}{*}{ Fishing gear } & \multirow{2}{*}{ Season } & \multicolumn{2}{|c|}{ Autumn } & \multicolumn{2}{|c|}{ Winter } & \multicolumn{2}{|c|}{ Spring } \\
\hline & & $P$ of $a$ & $P$ of $b$ & $P$ of $a$ & $P$ of $b$ & $P$ of $a$ & $P$ of $b$ \\
\hline \multirow[t]{3}{*}{ All gears combined } & Winter & $*$ & $*$ & & & & \\
\hline & Spring & $*$ & $*$ & $*$ & $*$ & & \\
\hline & Summer & $*$ & $*$ & $*$ & $*$ & $*$ & $*$ \\
\hline \multirow{3}{*}{$\begin{array}{l}\text { Nordic type benthic and pelagic multi- } \\
\text { mesh gillnets }\end{array}$} & Winter & $*$ & $*$ & & & & \\
\hline & Spring & $*$ & $*$ & ns & $*$ & & \\
\hline & Summer & $*$ & $*$ & $*$ & $*$ & $*$ & $*$ \\
\hline \multirow[t]{3}{*}{ Encircled towed fishing gear } & Winter & $*$ & $*$ & & & & \\
\hline & Spring & ns & $*$ & * & $*$ & & \\
\hline & Summer & $*$ & $*$ & $*$ & $*$ & $*$ & $*$ \\
\hline
\end{tabular}

ficult to be determined and might be attributed to the effect of one or more of the following factors: (a) the fishing down effect that gradually caused a decline in the large-size specimens of the population under study, (b) intra-and interspecifc interactions that can be reflected on the decrease of the LWR parameters (especially of the mid-trophic level species) (MOUTOPOULOS et al., 2011) and (c) unpredictable temperature and salinity variations potentially influencing fish species recruitment, especially of the smallpelagics, such as $A$. boyeri (BARTULOVIĆ et al., 2006), and feeding (DOULKA et al., 2013).

\section{AKNWOWLEDGEMENTS}

This study was performed in the framework of the research project "Development of management tools for marine and freshwater ecosystems - ANATHALLOI", undertaken by the Hellenic Center for Marine Research and funded by Greece and the European Union in the framework of the Operational Program "Competitiveness, Entrepreneurship \& Innovation" 2014-2020 (MIS code 5002500). The authors want to thank professional fisherman Nikolaos Zarkadas, as well as Roberta Barbieri, Georgia Papantoniou and Kostantinos Fostiropoulos for their assistance in fish sampling. 


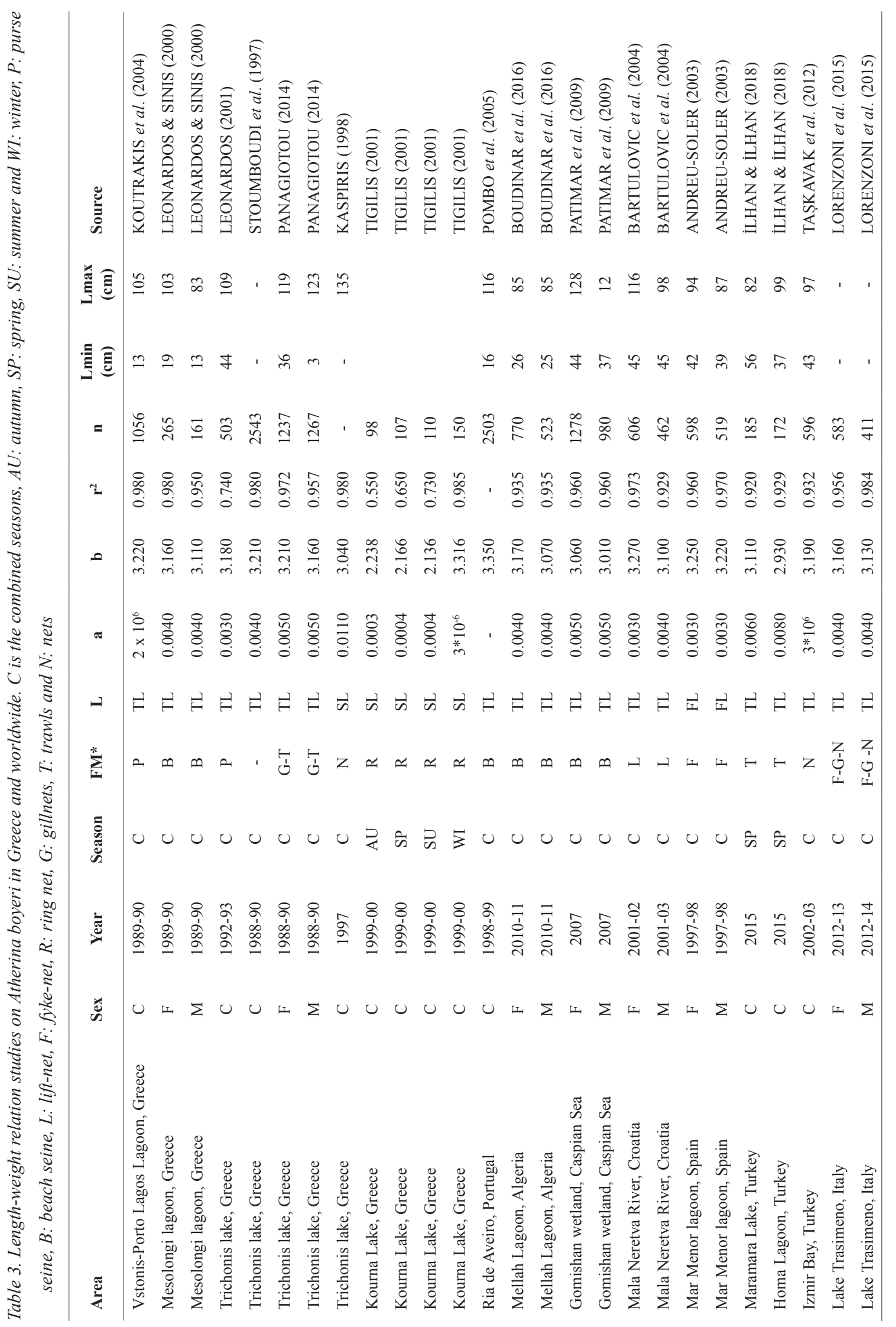




\section{REFERENCES}

ANDREU-SOLER, A., F. J. OLIVA-PATERNA, C. FERNADEZ-DELGADO \& M. TORRALVA. 2003. Age and growth of the sand smelt, Atherina boyeri (Risso 1810), in the Mar Menor coastal lagoon (SE Iberian Peninsula). J. Appl. Ichthyol., 19: 202-208.

BAGENAL, T. B. \& F. W. TESCH. 1978. Age and growth. In: Methods for assessment of fish production in freshwater, Bagenal T.B. (Editors), 3rd edition. Blackwell Scientific Publication, Oxford, U.K, pp. 101-136.

BARTUlović, V., B. GLAMUZINA, A. CONIDES, A. GAVRILOVIĆ \& J. DULČIĆ. 2006. Maturation, reproduction and recruitment of the sand smelt, Atherina boyeri Risso, 1810 (Pisces: Atherinidae) in the estuary of Mala Neretva River (southeastern Adriatic, Croatia). Acta Adriat., 47(1): 5-11.

BARTUlOVIĆ, V., B. GLAMUZINA, A. CONIDES, J. DULČIĆ, D. LUĆIČ, J. NJIRE \& V. KOŽUL. 2004. Age, growth, mortality and sex ratio of sand smelt, Atherina boyeri Risso, 1810 (Pisces: Atherinidae) in the estuary of the Mala Neretva River (middle-eastern Adriatic, Croatia). J. Appl. Ichthyol., 20: 427-430.

BOLGER, T. \& P. L. CONNOLLY. 1989. The selection of suitable indices for measurement and analysis of fish condition. J. Fish Biol., 34: 171-182.

BOUDINAR, A. S., L. CHAOUI \& M. H. KARA. 2016. Age, growth and reproduction of the sand smelt Atherina boyeri Risso, 1810 in Mellah Lagoon (Eastern Algeria). J. Appl. Ichthyol., 32: 302-309.

CEN 2005. EN 14757. Water quality-Sampling of Fish with Multimesh Gillnets. European Committee for Standardization. EN 14757 Brussels.

DAOULAS, Ch., A. ECONOMOU, Th. PSARRAS, R. BARBIERI-TSELIKI, K. ANASTASOPOULOU, Th. KOUSOURIS, A. DIAPOULIS, H. BERTACHAS, B. PAKOS \& K. GRITZALIS 1993. Limnological, ichthyological and fishing exploration of Lake Trichonida. HCMR Technical Report, $177 \mathrm{pp}$.

DOULKA, E., G. KEHAYIAS, E. CHALKIA \& I. D.
LEONARDOS. 2013. Feeding strategies of Atherina boyeri (Risso 1810) in a freshwater ecosystem. J. Appl. Ichthyol., 29: 200-207.

FROESE, R. \& D. PAULY. 2019. FishBase. World Wide Web electronic publication. www.fishbase.org, version (12/2019).

ILHAN, A. \& D. ILHAN. 2018. Length- Weight Relationship and Condition of sand smelt (Atherina boyeri Risso, 1810) Caught from Marmara Lake (Manisa) and Homa Lagoon (Izmir). Black Sea J. Sci 8 (1): 25-34.

KASPIRIS, P. 1998. Final report of a research of fisheries exploitation of sand smelt on Lake Trichonida. University of Patras, Biology department, $40 \mathrm{pp}$.

KOTTELAT, M. \& J. FREYHOF. 2007. Handbook of European freshwater fishes. Publications Kottelat, Comol and Freyhof, Berlin.646 pp. KOUTRAKIS, E. T., N. I. KAMIDIS \& I. D. LEONARDOS. 2004. Age, growth and mortality of a semi-isolated lagoon population of sand smelt, Atherina boyeri (Risso, 1810) (Pisces: Atherinidae) in an estuarine system of northern Greece. J. Appl. Ichthyol., 20: 382-388.

KYRITSI, S. \& A. K. KOKKINAKIS. 2019. LengthWeight relations and condition factor of roach Rutilus rutilus (Linnaeus, 1758) in Lake Volvi (Northern Greece). Acta Adriat., 60(1): 53-60.

LE CREN, E. D. 1951. The length-weight relationship and seasonal cycle in gonad weight and condition in perch (Perca fluviatilis). J. Animal Ecol., 20: 201-219.

LEONARDOS, I. \& A. SINIS. 2000. Age, growth and mortality of Atherina boyeri Risso, 1810 (Pisces: Atherinidae) in the Mesolongi and Etolikon lagoons (W. Greece). Fish. Res., 45: 81-91.

LEONARDOS, I. D. 2001. Ecology and exploitation pattern of a landlocked population of sand smelt, Atherina boyeri (Risso 1810), in Trichonis Lake (Western Greece). J. Appl. Ichthyol., 17: 262-266.

LORENZONI, M., D. GIANNETTO, A. CAROSI, R. DOLCIAMI, L. GHETTI \& L. POMPEI. 2015. Age, growth and body condition of big-scale sand 
smelt Atherina boyeri Risso, 1810 inhabiting a freshwater environment: Lake Trasimeno (Italy). Knowl. Manag. Aquat. Ec., 416, 09. MOUTOPOULOS, D. K., V. VAVAROUTA, A. RAMFOS, K. KOUKOU \& G. KATSELIS 2011. Investigation of length-weight relationships for $10 \mathrm{com}$ mercial fish species as a possible trophic state index of coastal lagoons. Acta Adriat., 52 (2): 261-268.

PANAGIOTOU, E. 2014. Biology of atherina reproduction, Atherina boyeri (Risso 1810) in Lake Trichonida. Postgraduate thesis, Aristotle University of Thessaloniki, $134 \mathrm{pp}$.

POMBO, L., M. ELLIOT \& J. E. REBELO. 2005. Ecology, age and growth of Atherina boyeri and Atherina presbyter in the Ria de Aveiro, Portugal. Cybium, 29(1): 47-55.

QUIGNARD, J. P. \& A. PRAS. 1986. Atherinidae. p. 1207-1210. In Whitehead, P.J.P., Bauchot, M.-L., Hureau, J.-C., Nielsen, J., Tortonese, E. (Editors.) Fishes of the North-eastern Atlantic and the Mediterranean. UNESCO, Paris. Vol. 3.

PATIMAR, R., M. YOUSEFI \& S. M. HOSIENI. 2009. Age, growth and reproduction of the sand smelt Atherina boyeri Risso, 1810 in the Gomishan wetland - southeast Caspian Sea. Estuar. Coast. Shelf S., 81: 457-462.
PETRIKI, O., D. K. MOUTOPOULOS, K. TSAGARAKIS, I. TSIONKI, G. PAPANTONIOU, I. MANTZOUNI, R. BARBIERI \& M. Th. STOUMBOUDI. 2021. Assessing the Fisheries and Ecosystem Structure of the Largest Greek Lake (Lake Trichonis). Water, 13, 3329.

STOUMBOUDI, M. Th., Th. PSARRAS \& R. BARBIERI-TSELIKI. 1997. Reproductive cycles of atherina (Atherina boyeri R1sso 1810) from Trichonis Lake (Greece). In: Proceedings of the Fifth National Symposium on Oceanography and Fisheries, 15-18 April 1997, Kavala, Greece, pp. 257-260 (in Greek, with English abstract).

TAŞKAVAK, E., Ş. GÜRKAN \& B. BAYHAN. 2012. Biometric properties of the sand smelt Atherina boyeri Risso, 1810 from the Izmir Bay (Aegean Sea). Taşkavak ve ark., 6(1): 18-25.

TIGILIS, G. 2001. Contribution to the knowledge of biological and ecological parameters of the indigenous populations of sand smelt (Atherina boyeri, Risso 1810) \& the freshwater blenny (Blennius fluviatilis, Asso 2801) lake Kourna Chania, Crete. Postgraduate thesis, $160 \mathrm{pp}$.

WOOTTON, R. J. 1999. Fish Ecology. Chapman and Hall, New York, 212 pp.

ZAR, J. H. 1999. Biostatistical analysis. (Fourth Edition). Prentice Hall, Upper Saddle River, $207 \mathrm{pp}$.

Received:20 November 2020

Accepted: 11 November 2021 


\section{Dužinsko - maseni odnosi i kondicijski čimbenici gavuna veleljuskaša Atherina boyeri (Risso, 1810) iz komercijalnih i eksperimentalnih ulova u jezeru Trichonis (zapadna Grčka)}

Alexandra DOULIGERI, Ioanna TSIONKI, Olga PETRIKI, Dimitrios K. MOUTOPOULOS,* i Maria Th. STOUMBOUDI

*Kontakt e-pošta: dmoutopo@upatras.gr

\section{SAŽETAK}

Dužinsko-maseni odnosi $\left(\mathrm{LWR}_{\mathrm{s}}\right)$ su izračunati za 3583 jedinke gavuna veleljuskaša Atherina boyeri (Risso, 1810) ulovljenih u jezeru Trichonis (Zapadna Grčka), tijekom razdoblja 2019-2020, Jedinke su ulovljene komercijalnim mrežama i eksperimentalnim mrežama nordijskog tipa bentoskih i pelagičnih mreža različitih oka. Varijacija parametra b za sva godišnja doba bila je značajno alometrijska, i za zaokružne povlačne mreže i za mreže stajačice, s prilično robusnim vrijednostima koeficijenta korelacije $\left(\mathrm{r}^{2}\right.$ je 0,925 odnosno 0,947$)$ i vrijednostima jednakim 2,254 odnosno 2,089. Primjerci su ljeti bili znatno lakši nego u ostalim godišnjim dobima. Nagibi LWR-a značajno se razlikuju između godišnjih doba i pokazali su relativno niske vrijednosti u usporedbi s drugim ekosustavima diljem svijeta i u istom ekosustavu u prethodnim vremenskim razdobljima. Procijenjene vrijednosti Le Crenovog indeksa bile su znatno veće od alometrijskih i Fultonovih.

Ključne riječi: veličina tijela; zaokružne povlačne mreže, mreže stajačice; Grčka 
